\title{
Developments in Indiana ApPellate Procedure: Rule AmEndments, Remarkable CASE LAW, AND COURT Guidance for ApPellate Practitioners
}

\author{
BRYAN H. BABB* \\ BRADLEY M. DICK ${ }^{* *}$
}

\section{INTRODUCTION}

The Indiana Supreme Court promulgates the Indiana Rules of Appellate Procedure ("Appellate Rules" or "Rules"), and Indiana's appellate courts - the Indiana Supreme Court ("Supreme Court"), the Indiana Court of Appeals ("Court of Appeals"), and the Indiana Tax Court - interpret and apply the Rules. This Article summarizes amendments to the Rules, analyzes cases interpreting the Rules, and highlights potential pitfalls appellate practitioners should avoid. This Article does not cover every case interpreting the Rules that occurred during the survey period. ${ }^{1}$ Instead, it focuses on the most significant decisions.

\section{RULE AMENDMENTS}

In recent years, there have been significant changes to the Appellate Rules due to the advent of electronic filing, which became mandatory for attorneys on July $1,2016 .^{2}$ There were significantly fewer changes during this survey period.

The Indiana Supreme Court amended Appellate Rule 40(A)(2) to provide that a party that has not been permitted to proceed in the trial court in forma pauperis must submit a new form App. R. 40-1 and a revised form App. R. 40-2, which was previously App. R. 40-1, to the trial court. ${ }^{3}$ The Indiana Supreme Court also amended Rule 40(A)(4) to provide that if the trial court denies a party's motion to proceed in forma pauperis, then the party may file a motion seeking leave to do so with the Court of Appeals, using the new form App. R. 40-1. ${ }^{4}$ The Indiana Supreme Court amended Rule 40(B) to provide that a party before an

* Partner, Bose McKinney \& Evans LLP. B.S., 1989, U.S. Military Academy; M.S.B.A., 1994, Boston University; J.D., cum laude, 1999, Indiana University Maurer School of Law; Law Clerk to Justice Frank Sullivan, Jr. of the Indiana Supreme Court, 1999-2000.

** Partner, Bose McKinney \& Evans LLP. B.A., 2003, Indiana University; J.D., magna cum laude, 2010, University of Michigan Law School; Law Clerk to Chief Justice Loretta H. Rush of the Indiana Supreme Court, 2013-2014.

1. The survey period is between October 1, 2016, and September 30, 2017.

2. Press Release, Ind. Supreme Court, E-Filing Progress Continues with Certain Cases and Counties Requiring the Move Away from Paper (Apr. 12, 2016), http://www.in.gov/ activecalendar/EventList.aspx ?fromdate $=1 / 1 / 2016 \&$ todate $=12 / 31 / 2016 \&$ display $=$ Month\&type $=$ public\&eventidn $=245063 \&$ view $=$ EventDetails\&information_id $=241097 \quad[\mathrm{https}: / /$ perma.cc $/ 4 \mathrm{LLN}$ WTKF].

3. Order Amending Indiana Rules of Appellate Procedure, No. 94S00-1602-MS-86, 1 (Ind. Dec. 15, 2016) [hereinafter Dec. 15, 2016 Order], http://www.in.gov/judiciary/files/order-rules2016-1215-appellate.pdf [https://perma.cc/BUV7-5ZCE].

4. $I d$. 
administrative agency that desires to proceed in forma pauperis should file with the Court of Appeals a motion for leave to do so and an affidavit using the new form App. R. 40-1 and the revised form App. R. 40-2, which was previously App. R. $40-1 .{ }^{5}$

The Indiana Supreme Court amended Appellate Rule 14. ${ }^{6}$ Rule 14(B)(3) now provides that the appellant shall file electronically, rather than conventionally, a notice of appeal for discretionary interlocutory appeals. ${ }^{7}$ Similarly, Rule 14(C)(5) now provides that an interlocutory appeal of an order granting or denying class action certification shall be filed electronically. ${ }^{8}$

The Indiana Supreme Court amended Appellate Rule 49(A) to provide that any party shall file its appendix on or before filing its brief. ${ }^{9}$ Rule 49(A) no longer provides that an appellee shall file its appendix with its brief, since the Rule now permits the appellee to file its appendix before filing its brief. ${ }^{10}$ The Indiana Supreme Court amended Rule 50(D) to provide that appendices, while still limited to 250 pages, may now be up to fifty megabytes in size. ${ }^{11}$ Previously, appendices were limited to twenty megabytes in size. ${ }^{12}$ Similarly, Appendix A, Standards for Preparation of Electronic Transcripts, now provides that transcripts may be up to fifty megabytes in size. ${ }^{13}$

The Indiana Supreme Court amended Rule 2(Y) to provide that a user agreement must be in a form provided by the Indiana Office of Judicial Administration. ${ }^{14}$ Previously, the Rule had provided that the form would be provided by the Indiana Office Division of Judicial State Court Administration, so the amendment deleted the words "Division" and "State Court."15

Beginning in 2006, the Indiana Supreme Court,

in collaboration with the Court of Appeals and Tax Court, has issued standing orders authorizing the Clerk of the Indiana Supreme Court, Court of Appeals, and Tax Court ('Clerk') to issue a 'Notice of Defect' instead of immediately rejecting documents that are timely tendered for

5. Id. at 2 .

6. Order Amending Indiana Rules of Appellate Procedure, No. 94S00-1701-MS-5 (Ind. Aug. 3, 2016) [hereinafter Aug. 3, 2017 Order], http://www.in.gov/judiciary/files/order-rules-20170803-appellate.pdf [https://perma.cc/9HM2-3WXH].

7. Id. at 1.

8. Id.

9. Id. at 2 .

10. $I d$.

11. Id.

12. $I d$.

13. $I d$.

14. Order Amending Indiana Rules of Appellate Procedure, No. 94S00-1701-MS-5, 1 (Ind. Nov. 1, 2017) [hereinafter Nov. 1, 2017 Order], http://www.in.gov/judiciary/files/order-rules-20171101-appellate.pdf [https://perma.cc/D3EG-PNNV].

15. Id. 
filing but do not comply with the Appellate Rules. ${ }^{16}$

"Today we revise the standing order to reflect subsequent amendments made to the" Appellate Rules. ${ }^{17}$ The Indiana Supreme Court allows the Clerk to issue a Notice of Defect if one or more of the following items is missing, insufficient, or incomplete:

(1) A certificate of service, see Ind. Appellate Rules 24, 57(G)(7), 68(F);

(2) A necessary word count certificate, see App. Rs. 34(G)(2), 44(E) \& (F), 54(E), 57(G)(6);

(3) A required signature and/or identifying information, see App. Rs. 23(E) 6(A)(9), 46(B), 68(H);

(4) A required Table of Contents or Table of Authorities, see App. Rs. 46(A)(1) \& (2), 46(B), 46(E)(1), 50(A)(2), 50(B)(1), 50(C), $57(\mathrm{G})(2)$;

(5) For the first document filed after the Notice of Appeal by a party proceeding in forma pauperis, the material required by Appellate Rule 40(C);

(6) For a motion to proceed in forma pauperis, a copy of any affidavit supporting the request to proceed in forma pauperis that was filed with the trial court or an affidavit conforming to Form \#App. R. 40-2; or a copy of the order setting forth the trial court's reasons for denying the in forma pauperis status on appeal;

(7) For an Appearance, information required by Appellate Rule 16(B);

(8) For an Appendix, a verification of accuracy, see App. Rs. $50(\mathrm{~A})(2)(\mathrm{i}), 50(\mathrm{~B})(1)(\mathrm{f})$;

(9) For an Appellant's Brief, an accompanying copy of the trial court's written opinion, memorandum of decision, or findings of fact and conclusions relating to the issue(s) raised on appeal, see App. R. 46(A)(12);

16. In re Documents Tendered for Filing that Fail to Comply with Certain Rules of Appellate Procedure, 83 N.E.3d 62 (Ind. 2017).

17. Id. 
(10) For an Appellant's Brief in a criminal appeal where the sentence is at issue, an accompanying copy of the sentencing order, see App. R. 46(A)(12);

(11) For a Petition to Transfer, a brief statement, set out by itself on the page immediately following the front page, identifying the issue, question presented, or precedent warranting transfer, see App. R. 57(G)(1);

(12) For a Petition for Review or brief in response, a brief section entitled Reasons for Granting or Denying Review, set out by itself immediately before the Argument section, explaining why review should or should not be granted, see App. R. 63(I). ${ }^{18}$

The Clerk may issue a Notice of Defect for inclusion of any of the following prohibited items:

(13) Argument or other material inappropriate for an Appendix, see App. Rs. 50(A), 50(B);

(14) For any Brief, any additional documents, other than the appealed judgment or order, see App. Rs. 46(F), 46(H);

(15) For any document, information excluded from public access when the document is not accompanied by a Notice to Maintain Exclusion from Public Access, see App. R. 23(F)(3). ${ }^{19}$

Finally, the Clerk may issue a Notice of Defect if the document is otherwise defective because:

(16) One or more "form” violations exist, see App. Rs. 23(E), 34(G), 43, 51, 54(F), 63(I); and/or

(17) The document was conventionally filed but should have been electronically filed through the Indiana E-Filing System, see App. R. $68(\mathrm{C}){ }^{20}$

When the Clerk issues a Notice of Defect, the Clerk will stamp the document "received" on "the date it would have been deemed filed but for the $\operatorname{defect}(\mathrm{s})$. ."21 If the document is corrected, it shall be deemed timely filed." "Any time period

18. Id. at $62-63$.

19. Id. at 63 .

20. $I d$.

21. Id.

22. Id. 
for other parties to respond to the defective document shall be computed from the date the corrected document is served." ${ }^{23}$ If the document is not corrected, the Clerk shall return it. ${ }^{24}$ The Clerk is also free to provide notification of a defect "by other means if such notification and correction can be accomplished more expeditiously and without prejudice to the other parties." 25

\section{CASE LAW INTERPRETING APPELLATE RULES}

The Indiana Court of Appeals and Indiana Supreme Court issued a number of decisions analyzing the Appellate Rules, including further developing Indiana's jurisprudence on the timeliness of appeals and other issues.

\section{A. Appellate Court Jurisdiction}

In 2014, in In re Adoption of O.R., the Indiana Supreme Court held that Indiana's appellate courts had jurisdiction over an appeal, despite the tardy filing of the notice of appeal. ${ }^{26}$ In In re D.J. v. Indiana Department of Child Services, the Indiana Supreme Court noted that it had "previously held that a tardy notice of appeal forfeits the aggrieved party's right to appeal, but does not deprive a reviewing court of jurisdiction to hear the appeal." ${ }^{27}$ Building off that ruling, the Indiana Supreme Court held that "a premature notice of appeal . . is not fatal to appellate jurisdiction. ${ }^{28}$

In In re D.J., the trial court determined that children were in need of services. ${ }^{29}$ "A child-in-need-of-services (CHINS) determination is not a final judgment. Finality does not occur until the court, after a dispositional hearing, resolves such questions as what specific services are warranted and whether the child should be placed in an alternative living arrangement, either provisionally or permanently." ${ }^{30}$ The children's parents filed notices of appeal before the CHINS determination was final. ${ }^{31}$ The Court of Appeals dismissed the parents' appeal because it "concluded that it lacked jurisdiction." 32 The Indiana Supreme Court did "not take issue with the Court's decision to dismiss the appeal; it is never error to dismiss a forfeited appeal. The Court's only error was its stated reason for dismissal - lack of jurisdiction." ${ }^{33}$

The timing of orders in In re D.J. is important. ${ }^{34}$ On November 13, 2015, the

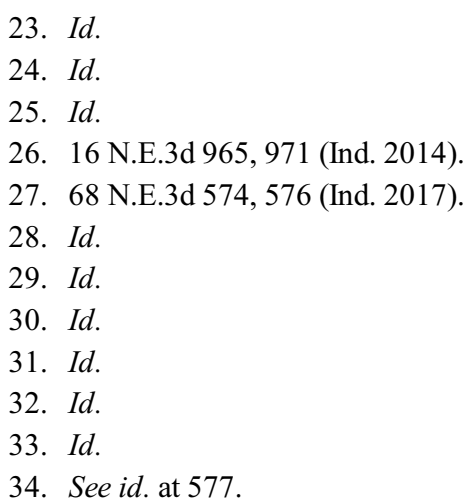


trial court found the children to be in need of services and set the matter for dispositional hearing on December $3 .^{35}$ The parents separately filed notices of appeal on December 11 and $14 .{ }^{36}$ On January 5, 2016, the trial court issued the dispositional order, prior to the Court of Appeals acquiring jurisdiction over the appeal. ${ }^{37}$ The Indiana Supreme Court emphasized that the parents filed their notices of appeal "after the court held the dispositional hearing but before it entered the dispositional order." 38 "After full briefing, the Court of Appeals dismissed Parents' appeal with prejudice based on lack of jurisdiction." ${ }^{\prime 39}$

The Indiana Supreme Court held that timely filing of a notice of appeal is not jurisdictional:

Despite the thirty-day requirement for filing a notice of appeal, timeliness is not a prerequisite to invoking appellate jurisdiction. Stated differently, the reviewing court is not deprived of jurisdiction if the notice is untimely - meaning belated or premature. The only two prerequisites under our appellate rules are (i) the trial court must have entered an appealable order, and (ii) the trial clerk must have entered the notice of completion of clerk's record on the CCS. ${ }^{40}$

The Indiana Supreme Court concluded that the parents had untimely filed their notice of appeal by filing it early, "[b]ut an untimely notice of appeal does not divest a reviewing court of jurisdiction." ${ }^{41}$ The Indiana Supreme Court then decided to hear the merits of the parents' appeals: "Given the purpose of our appellate rules, our preference for deciding cases on their merits, our Court of Appeals precedent, and the important parental interest at stake, we choose to disregard Parents' forfeiture and reach the merits.",42

Based on In re D.J., in Manley v. Zoeller, the Court of Appeals reasoned that "[u]ntil recently, it was understood that the lack of a final appealable order impacted an appellate court's 'jurisdiction' to entertain an appeal and that dismissal of the appeal was required in such situations." ${ }^{.43}$ The Court of Appeals concluded that the Indiana Supreme Court "has effectively overruled cases" that held that lack of a final appealable order deprived an appellate court of jurisdiction, and the Court of Appeals concluded that the Indiana Supreme Court had "held that, although a party who pursues an appeal from a non-final judgment has 'forfeited' the right to appeal, the appellate court still has 'jurisdiction' to consider the appeal on the merits." 44

35. Id.

36. $I d$.

37. Id.

38. Id.

39. Id.

40. Id. at 578 .

41. Id. at 579 .

42. Id. at 580 .

43. 77 N.E.3d 1227, 1230 (Ind. Ct. App. 2017).

44. Id. at 1231 . 
Another panel of the Court of Appeals disagreed with this conclusion. ${ }^{45}$ In Indy Auto Man, the trial court did not grant summary judgment in favor of all parties, and the trial court's summary judgment order did not "include the 'magic language' of Indiana Trial Rule 56(C)." ${ }^{" 46}$ Indy Auto Man appealed. ${ }^{47}$ The Court of Appeals concluded the trial court's order was not a final order because it did not dispose of all claims as to all parties. ${ }^{48}$ Appellate Rule 2(H)(1) provides that an otherwise non-final judgment may be deemed final if the trial court expressly determines "that there is no just reason for delay," among other requirements. ${ }^{49}$ The Court of Appeals then held that

if a trial court's summary judgment order is not final as to all issues, claims, and parties, the order must include the 'magic language' set forth in Trial Rule 56(C) to be considered final. Otherwise, a summary judgment order disposing of fewer than all claims as to all parties remains interlocutory in nature. ${ }^{50}$

The Court of Appeals then concluded that "[g]enerally, a non-final order is not appealable unless it is an interlocutory order that is appealable as of right under Appellate Rule 14(A), or the appellant has sought and gained permission for a discretionary interlocutory appeal from the trial court and this court under Appellate Rule 14(B). ${ }^{.51}$ The Court of Appeals concluded that neither of those provisions applied. ${ }^{52}$ As a result, the Court of Appeals concluded that because "we do not have jurisdiction to hear an appeal from the trial court's non-final summary judgment order, we dismiss this appeal, without prejudice." ${ }^{33}$

In a footnote, the Court of Appeals recognized that its conclusion conflicted with the Court of Appeals' decision in Manley. ${ }^{54}$ The Court of Appeals found that "[u]nlike the court in Manley, we do not read In re D.J. as altering the longstanding rule that appellate courts have no jurisdiction to consider non-final orders." ${ }_{55}$ "Instead, we read In re D.J. as merely applying our supreme court's existing rule that the timeliness of a notice of appeal does not affect an appellate court's jurisdiction., ${ }^{56}$

45. Indy Auto Man, LLC v. Keown \& Kratz, LLC, 84 N.E.3d 718 (Ind. Ct. App. 2017). While Indy Auto Man is not within the survey period, it and a subsequent Indiana Supreme Court decision resolve an issue of appellate practice that it would not make sense to leave unresolved until the next survey period article is published.

46. Id. at 719 .

47. Id.

48. Id. at 720 .

49. Id. (quoting Appellate Rule 2(H)(1)).

50. Id.

51. Id. at 721 .

52. Id. at 721-22.

53. Id. at 722 .

54. Id. at 720 n.2.

55. Id.

56. Id. 
The Indiana Supreme Court then resolved the confusion:

Nothing in D.J. eliminated or relaxed the requirements for appellate jurisdiction. It reaffirmed that the prerequisites for appellate jurisdiction are (1) entry of an appealable order by the trial court and (2) the trial court clerk's entry of the notice of completion of the clerk's record on the chronological case summary ("CCS"). 68 N.E.3d at 578. D.J. explained that in a child in need of services ("CHINS") case, the CHINS determination is not a final judgment and that finality does not occur until the court enters a dispositional order. $I d$. at 576. There, the trial court found the children to be CHINS, the parents then filed their separate notices of appeal, the court thereafter entered its dispositional order, and the clerk later filed the notice of completion of the clerk's record. $I d$. at 577. Appellate jurisdiction was secure in D.J. because the trial court entered its dispositional order - a final judgment - before the clerk entered the notice of completion of clerk's record on the CCS. Under Appellate Rule 8, the notice of completion of clerk's record is the document having jurisdictional significance, depriving the trial court of jurisdiction and conferring jurisdiction in the appellate court. Although the parents had already filed their notices of appeal, the trial court still had jurisdiction to enter a final judgment because the clerk had not yet entered the notice of completion of clerk's record on the CCS, and we concluded the parents' "premature notices of appeal did not deprive the Court of Appeals of jurisdiction to hear the appeal." Id. at 581.

Here, unlike in D.J., the record on appeal shows no final judgment. Indiana Appellate Rule 2(H) defines a judgment as a "final judgment" if, among other things, it disposes of all claims as to all parties or the trial court expressly determines in writing that there is no just reason for delay and expressly directs entry of judgment under Indiana Trial Rule 54(B) as to fewer than all the claims or parties, or under Indiana Trial Rule 56(C) as to fewer than all the issues, claims, or parties. The Order left the preliminary injunction in place, did not rule on DeSpirito's request for damages or a permanent injunction, and did not determine there is no just reason for delay and expressly direct entry of judgment on less than all of the issues, claims, or parties. ${ }^{57}$

The Indiana Supreme Court then remanded the matter back to the trial for a determination whether "there is no just reason for delay." ${ }^{88}$ The Indiana Supreme Court then concluded that "[n]othwithstanding Appellate Rule 65(E), this opinion is effective immediately, and the trial court need not await a certification of this opinion by the Clerk of Courts before exercising the limited jurisdiction this remand allows." ${ }^{59}$ Appellate Rule 65(E) provides that the Clerk "shall certify the

57. Town of Ellettsville v. DeSpirito, 87 N.E.3d 9, 11-12 (Ind. 2017) (per curiam).

58. Id. at 12 .

59. Id. 
opinion or memorandum decision to the trial court or Administrative Agency only after the time for all Petitions for Rehearing, Transfer, or Review has expired, unless all the parties request earlier certification." ${ }^{{ }^{60}}$ Rule 65(E) continues that the "trial court, Administrative Agency, and parties shall not take any action in reliance upon the opinion or memorandum decision until the opinion or memorandum decision is certified." $" 61$

The Court of Appeals also continued to address when an appellate court should hear an appeal on the merits. In Cannon v. Caldwell, the Court of Appeals addressed sua sponte whether Cannon had timely appealed a trial court ruling. ${ }^{62}$ The trial court modified Cannon's child support, and he filed a motion to reconsider. ${ }^{63}$ After the trial court ruled on the motion to reconsider, Cannon filed a notice of appeal, but he filed it more than thirty days after the appealed order. ${ }^{64}$ Caldwell, who had initiated the motion to modify child support, did not file an appellee's brief. ${ }^{65}$

The Court of Appeals addressed sua sponte whether Cannon had forfeited his right to appeal. ${ }^{66}$ "Our Appellate Rules require that a party initiate an appeal by filing a notice of appeal within thirty days after the entry of a final judgment is noted in the CCS." ${ }^{67}$ The Court then observed that Cannon filing a motion to reconsider did not toll the time to file a notice of appeal. ${ }^{68}$ The Court concluded that Cannon's "notice of appeal was untimely." ${ }^{69}$ But that did not end the story.

The Court continued its analysis, observing that "[o]ur supreme court has made clear that 'although a party forfeits its right to appeal based on an untimely filing of the Notice of Appeal, this untimely filing is not a jurisdictional defect depriving the appellate courts of authority to entertain the appeal." ${ }^{\prime 70}$ Instead, "the right to appeal having been forfeited, the question is whether there are extraordinarily compelling reasons why this forfeited right should be restored."71 The Court of Appeals noted that "[ $\mathrm{t}]$ his introduced a new concept into Indiana law: what does 'extraordinarily compelling reasons' mean in this context?" 72

After reviewing the Indiana Supreme Court's O.R. decision, the Court of Appeals then listed unanswered questions:

The O.R. court's analysis leaves several important questions unanswered.

60. IND. R. APP. P. 65(E).

61. Id.

62. 74 N.E.3d 255, 257 (Ind. Ct. App. 2017).

63. Id. at 256 .

64. Id. at 256-257.

65. Id. at 256 .

66. Id. at 257.

67. Id. (citing IND. R. ApP. P. 9(A)(1)).

68. Id. (quoting IND. Trial R. 53.4(A)).

69. Id.

70. Id. (quoting In re Adoption of O.R., 16 N.E.3d 965, 971 (Ind. 2014)).

71. Id. (quoting In re Adoption of O.R., 16 N.E.3d at 971).

72. Id. 
Do extraordinarily compelling reasons depend on the appellant's absence of fault or a finding of excusable neglect, or is it based on the nature of the right(s) at stake or the manifest injustice of the result? What combination of these factors is necessary to find extraordinarily compelling reasons, and how should they be weighed and balanced? As the $O . R$. court explained, the Appellate Rules exist to achieve orderly and speedy justice, and Appellate Rule 1 permits us to deviate from the rules. But in deciding whether it is appropriate to deviate from the rules, is our emphasis to be on order or justice? Is uniformity in the application of the rules itself a form of justice? Might our deviation from the rules in some cases but not others be perceived as unjust? ${ }^{73}$

The Court of Appeals concluded that because the trial court's order "is on its face in clear violation of the Child Support Guidelines . . this obvious injustice is an extraordinary compelling reason to restore [Cannon's] forfeited right to appeal and decide the appeal on the merits." ${ }^{\prime 4}$ The Court of Appeals then offered the following observation: "Unless and until our supreme court further defines extraordinarily compelling reasons and we can discern its actual elements rather than merely looking at the result, we must conclude that a manifestly unjust result constitutes an extraordinarily compelling reason to reach the merits of an otherwise forfeited appeal.","

In Estate of Mills-McGoffney v. Modesitt, the trial court dismissed a complaint under Indiana Trial Rule 41(E) for failure to prosecute. ${ }^{76}$ A year later the plaintiff filed a motion under Indiana Trial Rule $41(\mathrm{~F})$ to reinstate the complaint, the trial court denied her motion, and she appealed. ${ }^{77}$ On appeal, McGoffney challenged, in part, the trial court's original dismissal of her complaint. $^{78}$ The Court of Appeals found that she had forfeited those issues because she failed to appeal the original dismissal within thirty days under Appellate Rule $9 .{ }^{79}$ The Court of Appeals, however, concluded that a motion for reinstatement under Indiana Trial Rule 41(F) could be brought more than thirty days after a dismissal, so McGoffney could appeal whether the trial court abused its discretion by denying her motion for reinstatement. ${ }^{80}$

\section{B. Voluntary Dismissal of an Appeal}

Appellate Rule 36(A) provides that an "appeal may be dismissed on motion of the appellant upon the terms agreed upon by all the parties on appeal or fixed

73. Id. at 258 (internal footnote omitted).

74. Id. at 259 .

75. Id.

76. 78 N.E.3d 700, 704 (Ind. Ct. App. 2017).

77. Id.

78. Id at 705 .

79. Id.

80. Id. 
by the Court." ${ }^{81}$ In Rogers v. Martin, the Indiana Supreme Court granted a petition to transfer, vacating the Court of Appeals opinion. ${ }^{82}$ After the Indiana Supreme Court held oral argument, the parties notified the court that they had settled the case, "contingent on approval by both the United States Bankruptcy Court and the Allen County Probate Court." "Subsequently, once the opinion had been nearly finalized, plaintiffs filed a motion to dismiss because the parties had reached a settlement." ${ }^{\prime 4}$ The Indiana Supreme Court emphasized that voluntary dismissal under Appellate Rule 36(A) was discretionary: an "appeal may be dismissed." ${ }^{85}$ The Court declined to permit the case to be voluntarily dismissed: "Given the importance of the legal issues in this case, we deny the motion to dismiss and publish this opinion, while respecting the settlement between the parties." $\$ 86$

\section{Final Judgments Under Appellate Rule 2(H)}

In McGee v. Kennedy, the Court of Appeals addressed whether a pre-trial motion to correct error constituted a final judgment under Appellate Rule 2(H)(4). ${ }^{87}$ Appellate Rule 2(H)(4) defines a final judgment to include "a ruling on either a mandatory or permissive Motion to Correct Error which was timely filed under Trial Rule 59." 88 In McGee, McGee allegedly crashed his car into Kennedy's car. ${ }^{89}$ Kennedy's complaint was file stamped more than two years after the crash. ${ }^{90}$ McGee answered that he negligently caused the crash, but he moved to dismiss because he contended the statute of limitations barred the complaint. ${ }^{91}$ Kennedy then filed a motion to correct error under Indiana Trial Rule 59, requesting that the Chronological Case Summary reflect that the complaint was timely deposited with a third-party carrier. ${ }^{92}$ The trial court granted the "motion to correct error and ordered that the Chronological Case Summary reflect a [timely filing date.] ${ }^{\prime 93}$ McGee appealed. ${ }^{94}$ After McGee filed his appellant's brief, the trial court held a hearing on McGee's motion to dismiss, granted the motion, and set aside the order on Kennedy's motion to correct error..$^{95}$ Kennedy then filed

81. IND. R. APP. P. 36(A).

82. 63 N.E.3d 316, 319-20 (Ind. 2016).

83. Id. at 320 n.2 (quoting parties' notification).

84. Id.

85. Id.

86. Id.

87. 62 N.E.3d 467 (Ind. Ct. App. 2016).

88. IND. R. APP. P. 2(H)(4).

89. McGee, 62 N.E.3d at 469.

90. Id.

91. Id.

92. Id.

93. Id. at 470 .

94. Id.

95. Id. 
her appellee's brief, "attempting to challenge on cross-appeal the dismissal of her complaint." 96

As to Kennedy's motion to correct error, the Court of Appeals noted that the "motion to correct error was filed and granted as a pre-trial motion." ${ }^{97}$ McGee claimed that his appeal was from a final judgment because Appellate Rule $2(\mathrm{H})(4)$ defines a final judgment as including "a ruling on either a mandatory or permissive Motion to Correct Error which was timely filed." ${ }^{98}$ The Court of Appeals concluded that "[w]e do not consider her pre-trial motion to be a 'timely' filing of a Motion to Correct Error defined as a final judgment by Appellate Rule 2(H)(4)." 99 The Court of Appeals also concluded the trial court lacked authority to dismiss the complaint while an appeal was pending. ${ }^{100}$

\section{Trial Court Jurisdiction During an Appeal}

In Young v. Young, a trial court found a husband violated a protective order during a divorce proceeding and modified it. ${ }^{101}$ The husband appealed. ${ }^{102}$ "After the appeal was perfected, . . . the trial court entered two further orders: one awarding [the wife] attorney's fees, and another" reinstating the original protective order. ${ }^{103}$ The Court of Appeals noted that the "court on appeal acquires jurisdiction over a case when the notice of completion of clerk's record is entered in the chronological case summary ('CSS')," under Appellate Rule 8. ${ }^{104}$ The Court of Appeals held that because the Court of Appeals had acquired jurisdiction, the trial court lacked jurisdiction to modify the protective order, so that order was "void and of no force or effect."105 In contrast, the Court of Appeals concluded that in "family law cases, trial courts retain jurisdiction to award attorney's fees, including appellate attorney's fees, even after perfection of an appeal."106

In another case where the issue of trial court jurisdiction during an appeal arose, "Kevin Campbell ('Campbell') brought a small claims action in Johnson Superior Court for the return of a dog, 'Snickers,' against Irenea George ('George'). The Johnson County magistrate entered an order giving Snickers to George." 107 That order, however, "was never signed or otherwise adopted by a

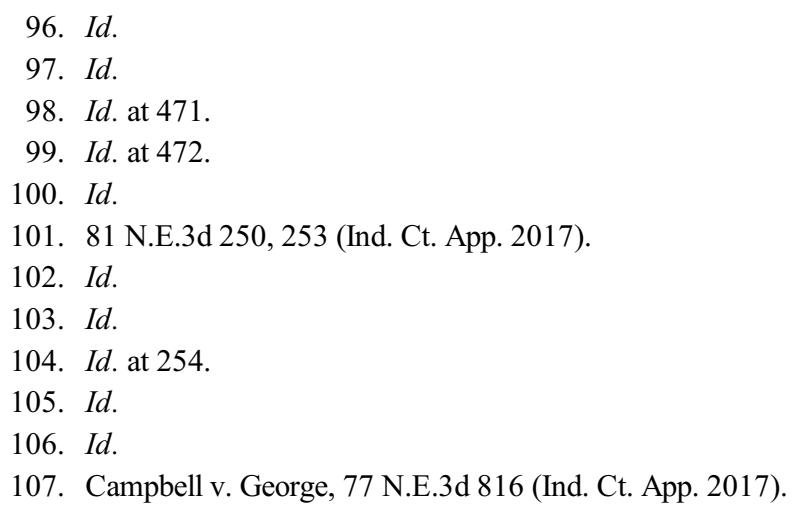


judge." ${ }^{108}$ Campbell appealed. ${ }^{109}$ While the appeal was pending, George filed a motion asserting that the Magistrate Judge lacked a judicial mandate, and "the superior court judge denied the motion for lack of jurisdiction under Indiana Appellate Rule 8."'110

\section{E. Remand for Further Proceedings}

Appellate Rule 37(A) provides that the Court of Appeals may remand a case to the trial court for further proceedings. ${ }^{111}$ In Muldowney v. Lincoln Park, LLC, a landlord brought a small claims action for immediate possession of a residence. ${ }^{12}$ The trial court held a hearing, but "no one was sworn in to testify and no exhibits were entered into evidence." ${ }^{113}$ Despite this, the trial court ordered the tenant evicted, and the tenant appealed. ${ }^{114}$ The Court of Appeals noted that "small claims trials should be informal," but "such informality does not mean that all rules of procedure may be blatantly disregarded."115 Under Appellate Rule 37(A), the Court of Appeals "remand[ed] this case for further proceedings and the conducting of a proper, if informal, evidentiary hearing."116

\section{REFINING OUR APPELLATE PROCEDURE}

During the survey period, the Indiana Supreme Court and the Indiana Court of Appeals offered advice to practitioners to help them avoid various appellaterule pitfalls.

\section{A. Appellants Should Follow Appellate Rule 14(B) 's Certification Procedure}

In In re Tr.S, a trial court ordered a permanency plan for children to be finalized and set the matter for a hearing. ${ }^{117}$ The mother appealed, contending the order should be characterized as a final order. ${ }^{118}$ The Court of Appeals concluded that the trial court's order was not a final judgment under Appellate Rule 2(H). ${ }^{119}$ The Court of Appeals noted that the mother "could challenge the trial court's decision to terminate reunification services by filing an interlocutory appeal." 120 "Indiana Appellate Rule 14(B) outlines the certification procedure for parties

108. Id

109. Id. at 817 .

110. Id.

111. IND. R. APP. P. 37(A).

112. 83 N.E.3d 130, 132 (Ind. Ct. App. 2017).

113. Id.

114. Id.

115. Id.

116. Id. at 135-36.

117. 63 N.E.3d 1065, 1067 (Ind. Ct. App. 2016).

118. Id.

119. Id.

120. Id. at 1068 . 
pursuing an appeal from an interlocutory order. It describes the time for filing a motion requesting certification of an interlocutory order, content of the motion, and grounds for granting interlocutory appeals." ${ }^{21}$ The Court of Appeals concluded that "[b]ecause Rule 14(B) provides Mother an opportunity to bring her case before us properly, we decline to adopt her reasoning to consider this order a final judgment." 122 The Court of Appeals concluded that "[b]ecause Mother has not followed the proper procedure to seek a discretionary interlocutory appeal, we lack subject matter jurisdiction. Accordingly, we dismiss." 123

\section{B. Exercise Caution When Filing a Motion to Reconsider}

In Snyder v. Snyder, the trial court issued an order that did not dispose of all issues. ${ }^{124}$ The husband filed a "Motion to Correct Error." ${ }^{25}$ Five months later, the trial court ruled on the husband's motion to correct error, and the husband appealed that ruling. ${ }^{26}$ The Court of Appeals began by noting that "[u]nlike issues of timeliness, issues concerning finality of appealed judgments are jurisdictional in nature." 27 The Court of Appeals concluded that because the trial court's original order did not dispose of all issues and did not "contain the "magic language' set forth in T.R. 54(B)," it was not a final order. ${ }^{128}$ The Court of Appeals next concluded that the original order was an interlocutory order that was appealable by right under Appellate Rule 14(A)(1). ${ }^{129}$ "Husband did not, however, file his notice of appeal within the allotted time. Instead, he filed what he styled a 'Motion to Correct Error' with the trial court."'130

The Court of Appeals concluded that "motions to correct error are proper only after the entry of final judgment; any such motion filed prior to the entry of final judgment must be viewed as a motion to reconsider." 131 Importantly, "motions to reconsider do not toll the thirty-day time frame within which a party wishing to undertake an appeal must do so." ${ }^{132}$ The Court of Appeals cautioned that "filing a motion to reconsider following the entry of an appealable interlocutory order is an act 'fraught with danger' because such a motion does not extend the deadline for filing a notice of appeal." ${ }^{133}$ The Court of Appeals,

121. Id.

122. Id.

123. Id. at 1069 .

124. 62 N.E.3d 455, 457 (Ind. Ct. App. 2016)

125. Id. at 458 .

126. Id.

127. Id.

128. Id.

129. Id.

130. $I d$.

131. Id.

132. Id. at 459.

133. Id. 
therefore, concluded that husband's notice of appeal was untimely, and that no "extraordinarily compelling reasons to restore his forfeited right to seek interlocutory appeal" existed. ${ }^{134}$

\section{Court of Appeals Confirms the Proper Procedure to Follow When Seeking a Trial Rule 60(B) Motion During an Appeal}

The Indiana Supreme Court has "set forth the proper procedure to follow when a party wishes to pursue a Trial Rule 60(B) motion while an appeal is pending." 135 The Court of Appeals confirmed that the proper procedure to follow is the "Logal Procedure":

(1) The moving party files with the appellate court an application for leave to file his 60(B) motion. This application should be verified and should set forth the grounds relied upon in a specific and non-conclusory manner.

(2) The appellate court will make a preliminary determination of the merits of the movant's 60(B) grounds. In so doing the appellate court will determine whether, accepting appellant's specific, non-conclusory factual allegations as true there is a substantial likelihood that the trial court would grant the relief sought. Inasmuch as an appellate court is not an appropriate tribunal for the resolution of factual issues, the opposing party will not be allowed to dispute the movant's factual allegations in the appellate court.

(3) If the appellate court determines that the motion has sufficient merit, as described in the preceding paragraph, it will remand the entire case to the trial court for plenary consideration of the 60(B) grounds. Such remand order will terminate the appeal and the costs in the appellate court will be ordered taxed against the party procuring the remand. The decision to remand does not require the trial court to grant the motion. If the trial court denies the motion, the movant should file a motion to correct errors addressed to this denial, and appeal the denial. In this new appeal any of the issues raised in the original appeal may be incorporated, without being included in the second motion to correct errors.

(4) If the trial court grants the motion, the opposing party may appeal that ruling under the same terms as described in paragraph (3). The original appeal shall be deemed moot. ${ }^{136}$

134. Id.

135. Falatovics v. Falatovics, 72 N.E.3d 472, 477 (Ind. Ct. App. 2017). Indiana Trial Rule 60 (B) provides procedures to relieve a party from a judgment.

136. Id. at 477-78 (quoting Logal v. Cruse, 267 Ind. 83, 368 N.E.2d 235, 237 (1977) (citations 
In Falatovics, "Husband filed in the trial court his verified Trial Rule 60(B) Motion to set aside the dissolution decree" while his wife's appeal was pending. ${ }^{137}$ " $[\mathrm{T}]$ he trial court granted Wife's motion to dismiss, finding that Husband failed to follow the appropriate procedure for bringing his Trial Rule 60(B) Motions, and that therefore he had waived his arguments and was not entitled to an evidentiary hearing." ${ }^{138}$ The Court of Appeals affirmed the trial court's "dismissal of Husband's Trial Rule 60(B) Motions" for failure to follow the Logal Procedure. ${ }^{139}$

\section{Do Not Place Citation in Footnotes}

Appellate Rule 22 requires citations to conform to "a current edition of a Uniform System of Citation (Bluebook)." ${ }^{140}$ The Bluebook provides that in "nonacademic legal documents, such as briefs and opinions, citations generally appear within the text of the document directly after the propositions they support." ${ }^{141}$ In U.S. Bank, National Ass'n v. Jewell Investments, the Court of Appeals noted that the parties' "briefs fail to comply with our rules because their citations to the record are in footnotes rather than in the text of the document." ${ }^{142}$ Similarly, the Court of Appeals advised a party not to place citations in footnotes in Sperro LLC v. Ford Motor Credit Co. LLC. ${ }^{143}$

\section{E. Do Not Reproduce Exhibits in the Appendix}

Appellate Rule 29 provides that "documentary exhibit volumes shall be transmitted to the Clerk with the electronic Transcript, using the same method of transmission as the electronic Transcript." ${ }^{44}$ Appellate Rule 50(F) provides that "[b]ecause the Transcript is transmitted to the Court on Appeal pursuant to Rule 12(B), parties should not reproduce any portion of the Transcript in the Appendix."145 In Sperro, the Court of Appeals noted that parties" "appendices do not comply with the Indiana Rules of Appellate Procedure because they contain exhibits, which are considered part of the transcript and therefore are not to be reproduced in an appendix."146

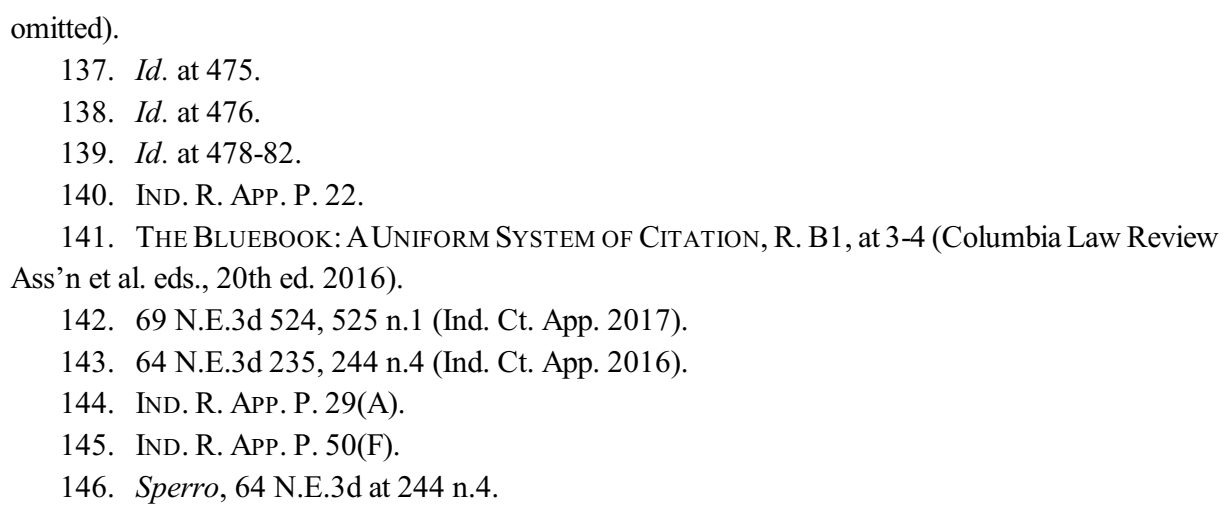




\section{F. Present Facts in Narrative Form}

The Court of Appeals reminded a litigant that Appellate Rule 46(A)(6)(C) "requires that the relevant facts be recounted 'in narrative form,' that is, in 'the form of a story.","147 The Court of Appeals explained that "[c]ompliance with this rule is particularly important in termination-of-parental-rights cases, where the key issue is often the progress (or lack thereof) made by a parent from the beginning of the case to the end." ${ }^{148}$

\section{G. File an Appellant's Appendix and Reference the Record on Appeal}

In Mundia v. Drendall Law Office, P.C., the Court of Appeals noted that a party, "contrary to Indiana Appellate Rule 50," had "failed to file an Appellant's Appendix and that, contrary to Indiana Appellate Rule 46, she has failed to support her Statement of Case and Statement of Facts with references to the record on appeal." 149 Appellate Rule 50 details the required contents of appellant's appendix. ${ }^{150}$ Appellate Rule 46 provides that for the statement of case, "[p]age references to the Record on Appeal or Appendix are required," and for the statement of facts, the "facts shall be supported by page references to the Record on Appeal or Appendix."151

\section{H. Do Not Cite Vacated Opinions}

The Court of Appeals reminded parties that they are not to cite vacated opinions:

In support of her earlier argument regarding the continuing wrong doctrine, Szamocki cites and relies on this Court's opinion in Manley [v. Sherer], 960 N.E.2d 815 (Ind. Ct. App. 2011), in which transfer was granted and the opinion vacated. See 992 N.E.2d 670 (Ind. 2013) (citing Ind. Appellate Rule 58(A)). When transfer is granted, the decision of the Court of Appeals is held for naught and has no precedential value. See Estate of Helms v. Helms-Hawkins, 804 N.E.2d 1260, 1268 n. 4 (Ind. Ct. App. 2004), trans. denied. Despite being aware of the vacated status of our prior opinion, counsel nevertheless urges us to consider the vacated opinion as "persuasive authority." Appellant's Br. at 17 n.1. We remind counsel that "naught" is defined as "nothing." MERRIAM-WEBSTER ONLINE DICTIONARY, https://www.merriamwebster. com/dictionary /naught (last visited Jan. 19, 2017). Accordingly, our vacated opinion in Manley cannot and will not be considered for any purpose. ${ }^{152}$

147. In re L.R., 79 N.E.3d 985, 986 n.1 (Ind. Ct. App.), trans. denied, 79 N.E.3d 700 (Ind. 2017) (citing Narrative, Webster's Third New International Dictionary (1993)).

148. Id.

149. 77 N.E.3d 846, 848 n.2 (Ind. Ct. App.), trans. denied, 92 N.E.3d 1089 (Ind. 2017).

150. IND. R. APP. P. 50(B).

151. IND. R. APP. P. 46(A)(5), (A)(6)(a).

152. Szamocki v. Anonymous Doctor \& Anonymous Grp., 70 N.E.3d 419, 428 n.4 (Ind. Ct. 


\section{INDIANA'S APPELLATE COURTS}

\section{A. Case Data from the Indiana Supreme Court}

During the 2017 fiscal year, ${ }^{153}$ the Indiana Supreme Court disposed of 879 cases, including 484 criminal cases, 246 civil cases, 5 tax cases, 46 original actions, 93 attorney discipline cases, 1 board of law examiners case, and 4 judicial discipline cases. ${ }^{154}$ The court heard fifty-nine oral arguments during the fiscal year, thirty-four percent of which were heard before the court decided to grant transfer. ${ }^{155}$ The court issued seventy-three majority opinions and fourteen non-majority opinions. ${ }^{156}$ Chief Justice Rush issued thirteen majority opinions, Justice Rucker issued nine majority opinions, Justice David issued eleven majority opinions, Justice Massa issued nine majority opinions, and Justice Slaughter issued five majority opinions. ${ }^{157}$ The court issued unanimous decisions seventy-seven percent of the time. ${ }^{158}$

\section{B. Justice Rucker Retires}

On January 19, 2017, Justice Robert D. Rucker announced his retirement "after 26 years on the bench." 159 Rucker was "Indiana's 105th Supreme Court justice. Rucker said, "It has been an honor to serve Hoosiers for a quarter century." " ${ }^{60}$ Chief Justice Rush "describe[d] Justice Rucker as a humble, brilliant, and conscientious public servant." 161 She said the following regarding Justice Rucker: “'Justice Rucker's contributions to Indiana's jurisprudence are remarkable. His legal scholarship is innovative and insightful in applying constitutional values. His body of work stands as a powerful illustration of the guidance courts provide for the peaceful resolution of disputes encompassing nearly every facet of Hoosier life.""162 "Prior to his Supreme Court appointment, Rucker served on the Indiana Court of Appeals having been appointed by

App.), trans. denied, 88 N.E.3d 1075 (Ind. 2017).

153. The Indiana Supreme Court 2017 fiscal year ran from July 1, 2016 to June 30, 2017. See Ind. Supreme Court, Indiana Supreme Court Annual Report 2016-17 (2017), https://www.in.gov/judiciary/supreme/files/1617report.pdf [perma.cc/9EGP-3GUF].

154. Id. at 11 .

155. Id. at 16 .

156. Id. at 18 .

157. Id.

158. Id.

159. Press Release, Ind. Supreme Court Justice Rucker Announces Spring 2017 Retirement (Jan. 19， 2017), http://in.gov/activecalendar/EventList.aspx?eventidn= 256170\&view $=$ EventDetails\& information_id $=254672 \&$ forceredirect $=Y$ [perma.cc/L9EX-7FNS].

160. Id.

161. Id.

162. Id. 
Governor Evan Bayh in 1991."163 Justice Rucker was "the first African American to serve on an Indiana appellate court," he "authored 1,235 civil and criminal opinions," and he was "a decorated veteran of the Vietnam War."164 Justice Rucker's service to our Country and State is greatly appreciated and will be missed.

\section{Justice Goff Joins the Indiana Supreme Court}

Governor Eric Holcomb appointed Justice Christopher M. Goff to the Indiana Supreme Court in June 2017, and Justice Goff "took the oath of office as Indiana's 110th justice on July 24, 2017."165 "Justice Goff was born in Wabash, Indiana in 1972. After graduating from high school there, he attended Ball State University graduating summa cum laude in 1994, and then earned his law degree at the Indiana University Maurer School of Law in 1996." 166 After law school, Justice Goff made "partner at a Huntington law firm after just 18 months working on criminal defense, domestic relations, personal injury, small business cases, and more." 167 Justice Goff then "served as Huntington County Public Defender for two years." "Justice Goff was named Huntington County Pro Bono Attorney of the Year in 2001 and 2002."169 "Before joining the Indiana Supreme Court, Justice Goff served as Wabash County Superior Court Judge for twelve years. During his service on the trial bench he established the Wabash County Drug Court and the Wabash County Family Drug Treatment Court." ${ }^{170}$ We look forward to watching the newest member of the Indiana Supreme Court over the coming years.

\section{Case Data from the Indiana Court of Appeals}

During 2016, ${ }^{171}$ the Court of Appeals disposed of 3,047 cases. ${ }^{172}$ This halted a multi-year trend of declining caseloads, with the court's caseload ticking up slightly from 2,920 cases in $2015 .{ }^{173}$ The court disposed of 1,728 criminal cases,

163. Id.

164. Id.

165. Justice Biographies: Hon. Christopher M. Goff, Ind. Supreme Court, http://www.in. gov/judiciary/citc/3955.htm [perma.cc/UHY9-S99P] (last visited Mar. 16, 2018).

166. Id.

167. Id.

168. Id.

169. Id.

170. Id.

171. The Indiana Court of Appeals 2016 annual report covers January 1, 2016 through December 31, 2016. See Ind. Court of Appeals, Indiana Court of Appeals 2016 Annual REPORT, http://www.in.gov/judiciary/appeals/files/2016-coa-annual-report.pdf [perma.cc/5VF9LQ54] (last visited Mar. 28, 2018).

172. Id. at 1 .

173. Id. 
949 civil cases, and 370 other cases. ${ }^{174}$ The court affirmed the trial court $82.3 \%$ of the time, with the court affirming $87.3 \%$ of criminal cases, $92 \%$ of postconviction relief cases, and $67.7 \%$ of civil cases. ${ }^{175}$ The average age of cases pending before the Court of Appeals at the end of 2016 was 1.4 months. ${ }^{176} \mathrm{In}$ addition to deciding cases, the court issued 7,535 orders. ${ }^{177}$

\section{CONCLUSION}

During the survey period, the Indiana appellate courts analyzed, interpreted, and applied the Appellate Rules. During the survey period, changes continued at the Indiana Supreme Court, with Justice Rucker retiring and Justice Goff becoming the newest justice.

174. Id.

175. Id. at 2 .

176. Id.

177. Id. 